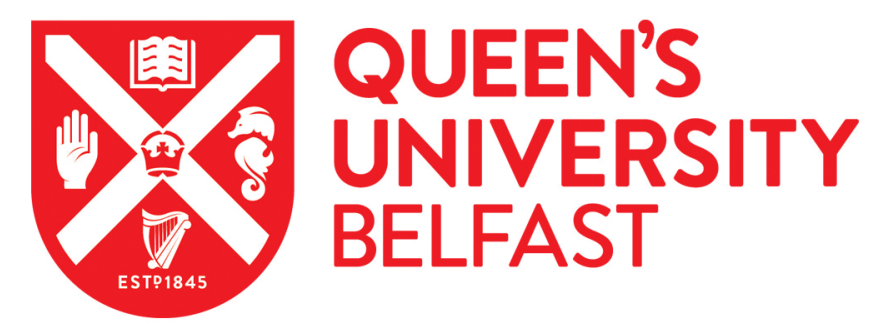

\title{
Graphene reinforced polyether ether ketone nanocomposites for bone repair applications
}

\author{
Jiang, N., Tan, P., He, M., Zhang, J., Sun, D., \& Zhu, S. (2021). Graphene reinforced polyether ether ketone \\ nanocomposites for bone repair applications. Polymer Testing. \\ https://doi.org/10.1016/j.polymertesting.2021.107276
}

\section{Published in:}

Polymer Testing

\section{Document Version:}

Publisher's PDF, also known as Version of record

\section{Queen's University Belfast - Research Portal:}

Link to publication record in Queen's University Belfast Research Portal

\section{Publisher rights}

Copyright 2021 the authors.

This is an open access article published under a Creative Commons Attribution-NonCommercial-NoDerivs License

(https://creativecommons.org/licenses/by-nc-nd/4.0/), which permits distribution and reproduction for non-commercial purposes, provided the author and source are cited.

\section{General rights}

Copyright for the publications made accessible via the Queen's University Belfast Research Portal is retained by the author(s) and / or other copyright owners and it is a condition of accessing these publications that users recognise and abide by the legal requirements associated with these rights.

Take down policy

The Research Portal is Queen's institutional repository that provides access to Queen's research output. Every effort has been made to ensure that content in the Research Portal does not infringe any person's rights, or applicable UK laws. If you discover content in the Research Portal that you believe breaches copyright or violates any law, please contact openaccess@qub.ac.uk. 


\title{
Graphene reinforced polyether ether ketone nanocomposites for bone repair applications
}

\author{
Nan Jiang ${ }^{\mathrm{a}, 1}$, Peijie Tan ${ }^{\mathrm{a}, 1}$, Miaomiao He ${ }^{\mathrm{a}}$, Jie Zhang ${ }^{\mathrm{a}}$, Dan Sun ${ }^{\mathrm{b}}$, Songsong Zhu ${ }^{\mathrm{a},{ }^{*}}$ \\ ${ }^{a}$ State Key Laboratory of Oral Diseases, \& National Clinical Research Center for Oral Disease, \& West China Hospital of Stomatology and the Research Center for Nano \\ Biomaterials, Analytical \& Testing Center, Sichuan University, Chengdu, 610041, China \\ ${ }^{\mathrm{b}}$ Advanced Composite Research Group (ACRG), School of Mechanical and Aerospace Engineering, Queens University Belfast, Belfast BT9 5AH, UK
}

\section{A R T I C L E I N F O}

\section{Keywords:}

Polyether ether ketone

PEEK

Graphene

Nanocomposites

Osteointegration

Bone repair

\begin{abstract}
A B S T R A C T
To improve the performance of polyether ether ketone matrix (PEEK) in hard tissue repair and replacement applications, we fabricated graphene nanoplatelet $(G)$ reinforced PEEK with different filler weight concentrations $(0.1 \%-5 \%)$ through injection moulding. The mechanical properties, surface morphology, chemical composition and thermal stability of the composites have been characterized. The biocompatibility has been assessed in vitro and the bone repair function of the composite implants have been assessed in vivo using a rabbit mandibular bone defect model. Mechanical testing results suggest that the composite samples have compressive moduli similar to that of the natural bone. Although addition of G into PEEK does not significantly influence the composite tensile, flexural or compressive moduli, it can significantly enhance the ductility and toughness of the material. On the other hand, all G-reinforced PEEK implants demonstrated enhanced adhesion and differentiation of rat bone marrow stromal cells (BMSCs), with 5\% G-PEEK showing the highest bioactivity among all samples. The in vivo osseointegration data further revealed that 5\% G-PEEK has the best effect in promoting osseointegration and bone regeneration, in both early stage and late stage bone re-growth. Study shows that our G-reinforced PEEKbased implants provides a promising strategy for enhancing the performance of future regenerative bone implants.
\end{abstract}

\section{Introduction}

In recent decades, the rapid increase of the global aging population and rise in orthopedic injuries/diseases have led to stronger demand in hard tissue implants. Traditionally, metal-based (e.g. Ti alloy, stainless steel) [1] hard tissue implants are commonly used to repair hard tissue defects [2,3]. However, the significant difference between the elastic moduli of these metallic implants and that of human bone can lead to the "stress-shielding" effect, which usually results in bone resorption/loss and eventually the implant failure [1]. As a result, revision surgeries are often required, which could lead to increased pain, risks of infections and hospital costs. To date, stress shielding still remains the on-going clinical concern in orthopedics and the demand for implants which can offer appropriate load-bearing capabilities are highly desirable.

Polyether ether ketone (PEEK) is a widely used engineering thermoplastic material $[4,5]$. In recent decades, it attracted great interest in the area of biomedical implants due to its excellent biocompatibility and mechanical properties similar to that of the natural bone [6]. It is radiolucent and remains stable during sterilization process [7, 8]. As a result, PEEK has been widely used in biomedical applications such as spine, skull and hip joint replacements $[9,10]$. Nevertheless, its lack of osteointegration due to bio-inertness may lead to formation of fibrous encapsulation followed by loosening/failure of the implant [11]. In order to address this issue, researchers have combined various bioactive nanomaterials, such as hydroxyapatite (HA) [12,13] and/or titanium dioxide $\left(\mathrm{TiO}_{2}\right)$ [14] nanoparticles with PEEK to create nanocomposites with improved osteoconductivity in vivo. However, these ceramic based materials, when used as bulk reinforcement, can easily agglomerate at higher concentration, which may damage the composites structural integrity and lead to stress concentration sites that

\footnotetext{
* Corresponding author. State Key Laboratory of Oral Diseases, \& National Clinical Research Center for Oral Disease, \& West China Hospital of Stomatology, Sichuan University Chengdu, Sichuan, 610064, China.

E-mail addresses: dent_jn@163.com (N. Jiang), 1779818175@qq.com (P. Tan), hemmiao@126.com (M. He), 1102739475@qq.com (J. Zhang), d.sun@qub.ac.uk (D. Sun), zss_1977@163.com (S. Zhu).

1 N. Jiang and P. Tan contributed equally to this work.
} 
Table 1

Recent studies on PEEK and its composite systems with graphene modification.

\begin{tabular}{|c|c|c|c|c|c|c|c|}
\hline Matrix & Fillers & Fabrication methods & $\begin{array}{l}\text { Key material } \\
\text { functionality }\end{array}$ & Targeted application & In vitro experiment & In vivo experiment & References \\
\hline PEEK & $\begin{array}{l}\text { Graphene } \\
\text { nanoplatelets }\end{array}$ & $\begin{array}{l}\text { Fused filament } \\
\text { fabrication }\end{array}$ & $\begin{array}{l}\text { Multifunctional } \\
\text { performance }\end{array}$ & $\begin{array}{l}\text { Orthopedics, oil and } \\
\text { gas, automotive, } \\
\text { electronics and space }\end{array}$ & Not performed & Not performed & [31] \\
\hline PEEK & $\begin{array}{l}\text { Graphene } \\
\text { nanoplatelets }\end{array}$ & $\begin{array}{l}\text { Melt-mixing } \\
\text { techniques }\end{array}$ & $\begin{array}{l}\text { High temperature } \\
\text { adhesives }\end{array}$ & A lap shear joint & Not performed & Not performed & [32] \\
\hline $\begin{array}{l}\text { PEEK/S: } \\
\text { PEEK/Short } \\
\text { carbon } \\
\text { fiber/PTFE } \\
\text { hybrid }\end{array}$ & $\begin{array}{l}\text { Graphene } \\
\text { nanoparticles }\end{array}$ & $\begin{array}{l}\text { Milling and melt } \\
\text { blending }\end{array}$ & $\begin{array}{l}\text { Improvement on } \\
\text { tribological } \\
\text { performance }\end{array}$ & $\begin{array}{l}\text { Polymeric engineer } \\
\text { materials design and } \\
\text { synthesis }\end{array}$ & Not performed & Not performed & [33] \\
\hline PEEK & $\begin{array}{l}\text { Graphene } \\
\text { nanoplatelets }\end{array}$ & $\begin{array}{l}\text { Melt and cold } \\
\text { crystallization }\end{array}$ & $\begin{array}{l}\text { Varied correlation } \\
\text { length of the crystal }\end{array}$ & $\begin{array}{l}\text { Crystallization change } \\
\text { and chain mobility of } \\
\text { polymer }\end{array}$ & Not performed & Not performed & [34] \\
\hline PEEK & $\begin{array}{l}\text { Carbon fiber/ } \\
\text { Graphene power }\end{array}$ & $\begin{array}{l}\text { PMMA-graphene } \\
\text { membrane bonding }\end{array}$ & $\begin{array}{l}\text { Bioactivity and } \\
\text { osseointegration } \\
\text { enhancement }\end{array}$ & $\begin{array}{l}\text { Implants for clinical } \\
\text { applications }\end{array}$ & $\begin{array}{l}\text { BMSCs attachment } \\
\text { and osteogenic } \\
\text { differentiation }\end{array}$ & $\begin{array}{l}\text { Rabbit extraarticular } \\
\text { graft-to-bone } \\
\text { healing model }\end{array}$ & [7] \\
\hline PEEK & $\begin{array}{l}\text { Graphene } \\
\text { nanoplatelets }\end{array}$ & $\begin{array}{l}\text { Melt-compounding } \\
\text { and injection- } \\
\text { moulding }\end{array}$ & $\begin{array}{l}\text { Thermal } \\
\text { conductivities } \\
\text { improvement }\end{array}$ & Not specified & Not performed & Not performed & [35] \\
\hline
\end{tabular}

compromise the composite tensile/fatigue properties [15], as well as toughness [12].

Over the past few years, functional nanomaterial graphene and its derivatives have been explored for diverse fields ranging from catalytic applications [16,17], sensing [18] to drug delivery [19,20], and tissue engineering [21], etc. In the tissue engineering field, graphene nanoplatelet (G) was found to promote adhesion, proliferation and osteogenic differentiation of human bone marrow stromal stem cells (BMSCs), showing their great potential in tissue regeneration [22,23]. Because of its excellent mechanical strength/stiffness as well as other unique functionalities such as high thermal/electrical conductivity [24-27] and photothermal conversion properties [28], G has been incorporated into a range of polymers to form nanocomposites for various structural and functional applications. To date, $\mathrm{G}$ has been incorporated into a wide range of polymers such as (PCL [28], PLA [29], hydrogels [30], etc) to produce nanocomposites for bioapplications, however, the studies on $\mathrm{G}$ reinforced PEEK nanocomposite is still in its infancy.

Table 1 summarized the recent studies of composite systems consist of $\mathrm{G}$ and PEEK. For instance, Yan developed $\mathrm{G}$ coated carbon fiberreinforced polyether ether ketone (CFR-PEEK) through a free-standing polymethyl methacrylate (PMMA)-G surface membrane, followed by dissolution of PMMA [7]. Results showed that the G surface modification could promote the proliferation and osteogenic differentiation of BMSCs on the implant surface. However, the interfacial interaction between $\mathrm{G}$ and the composite was not characterized and the longevity of the coating remains unknown. Arif et al. developed carbon nanotubes (CNT) and G reinforced PEEK composites and produced 3D printed structures through additive manufacturing utilizing in-house nanoengineered filaments [31]. The thermal and mechanical properties of their composites can be manipulated by adjusting the CNT/G ratio, however, the potential of such composite for biomedical applications has not been verified in vitro or in vivo. From the literature, no work has been conducted to date to investigate the tissue regeneration properties of melt-processed bulk reinforced G-PEEK composites.

In the present study, $\mathrm{G}$ reinforced PEEK nanocomposites were produced through injection moulding process. In comparison to other synthetic routes for manufacturing polymer nanocomposites (such as solution mixing, in situ polymerization, etc), injection moulding has the advantages of solvent free processing, scalable production, and excellent nanofiller dispersion achieved through low melting temperature and high shear [28]. The effect of G loading on the properties of the resulting composites has been investigated thoroughly using a wide range of characterization techniques. The biocompatibility and tissue regeneration ability of the composites were also evaluated in vitro and in vivo. To the best of our knowledge, this is the first development of injection molded $\mathrm{G}$ reinforced PEEK composites with desirable mechanical and biological performance which have been demonstrated successfully for hard tissue implant applications.

\section{Materials and methods}

\subsection{Materials and preparation}

PEEK powder (Jilin Joinature Polymer Co., Ltd., China) with average particle size of $25 \mu \mathrm{m}$ was dried at $80^{\circ} \mathrm{C}$ for $12 \mathrm{~h}$ before use. Graphene nanoplatelets (G, 5 layers) with average radial size of $2 \mu \mathrm{m}$ was purchased from the Sixth Element Materials Technology Co., Ltd (Changzhou, China). PEEK powder with different $\mathrm{G}$ weight concentration was mixed with absolute ethanol ( $1 \mathrm{~g}$ powder mixture in $10 \mathrm{ml}$ ethanol) and magnetically stirred for $30 \mathrm{~min}$ at room temperature. The PEEK/G mixture were then extracted by vacuum filtration and dried in a $60{ }^{\circ} \mathrm{C}$ oven until no further weight loss. G-PEEK composites with different $\mathrm{G}$ weight concentrations $(0,0.1,0.5,1,2,5 \%)$ were prepared by injection moulding using SJZS-10A mini conical twin-screw extruder (Ruiming Plastics Machinery Manufacturing Company, China) at $367{ }^{\circ} \mathrm{C}$ and a screw speed of $40 \mathrm{rpm}$. From the previous report, fully intermeshing, corotating twin screw was considered as one of the most effective methods of achieving high levels of dispersion and distribution for a range of nano-particles in highly viscous polymer melts [27]. Melt products were injected into metal mould using a mini-injection machine (SZS-20, Ruiming Plastics Machinery Manufacturing Company, China) to form compressive testing, tensile testing and flexural testing coupons, the dimensions of which comply with GB/T 9341-2008/ISO 178:2001, GB/T 1041-2008/ISO 604:2002, and GB/T 1040.1-2006/ISO 527-1:1993, respectively [21]. The finished coupons were annealed at $200{ }^{\circ} \mathrm{C}$ for $2 \mathrm{~h}$ and cooled down to room temperature naturally.

\subsection{Characterization}

The mechanical properties of all coupons were tested using a universal mechanical testing machine (MTS, model E45) following established methods [21]. The speed was set to $10 \mathrm{~mm} / \mathrm{min}$ for tensile test, and $4 \mathrm{~mm} / \mathrm{min}$ for compressive and flexural tests. Morphology of the tensile fractured section was analyzed using Scanning electron microscope (SEM, FEI Inspect F50, USA). The surface wettability was analyzed by measuring the contact angle using a surface tensiometer (TL101, Biolin Scientific $\mathrm{AB}$ ) at five random locations for each sample and the average was taken. X-ray diffraction (XRD, DX-2500, China) was used to 
investigate the crystal structure of PEEK and G-PEEK. Thermogravimetric analysis (TGA) and differential scanning calorimetry (DSC) were carried out by a thermal analysis system (TGA/DSC2, Switzerland) in the temperature range $25^{\circ} \mathrm{C}-1500{ }^{\circ} \mathrm{C}$ in $\mathrm{N}_{2}$ atmosphere at a heating rate of $20{ }^{\circ} \mathrm{C} / \mathrm{min}$. TEM images were recorded by Transmission electron microscope (TEM, Tecnai G2 F20 S-TWIN, FEI, USA).

\subsection{In vitro test}

BMSCs from 1-week-old SD rats (Chendu Dossy Experimental Animals CO., LTD , China) were cultured in $\alpha$ Minimum Eagle's medium ( $\alpha$-MEM, Gibco, USA) supplemented with $10 \%$ fetal bovine serum (FBS, Gibco, USA), and $1 \%$ penicillin and streptomycin (Hyclone, USA). The cells were incubated at $37{ }^{\circ} \mathrm{C}$ in a $95 \%$ humidified atmosphere with $5 \%$ $\mathrm{CO}_{2}$. The culture medium was replaced every 2 days. Cells of the 2 nd to 4 th passages were used for the following experiments.

\subsubsection{Cell proliferation}

Cell proliferation was tested using Cell Counting Kit-8 (APExBIO, USA) after the cells were cultured on the sample $(10 \mathrm{~mm} \times 10 \mathrm{~mm} \times 1$ $\mathrm{mm})$ surface for 1, 3, 5 and 7 days. For each group $(\mathrm{n}=3), 2 \times 10^{4}$ viable cells were seeded per sample with $\alpha$-MEM being the blank control. At each predetermined time interval, the samples were rinsed by phosphate-buffered saline (PBS) 3 times to remove unattached cells and transferred into a new 24-well plate, which contains $500 \mu \mathrm{L} \mathrm{10 \%} \mathrm{CCK-8}$ solution (APExBIO, USA) in each well. The plates were incubated in dark condition at $37{ }^{\circ} \mathrm{C}$ for $1 \mathrm{~h} 100 \mu \mathrm{L}$ solution from each group was transferred in triplicates into 96-well plates and read at $450 \mathrm{~nm}$ using a microplate reader (Multiskan FC, Thermo Scientific, America). Cell cycle was tested by Cell cycle detection kit (KeyGen BioTECH, Jiangsu) after being cultured for 3 days using flow cytometer (BECKMANCytomic FC 5000). Briefly, cells from each group were collected, fixed with ethanol and co-cultured with propidium iodide (PI) for $30 \mathrm{~min}$. The cell cycle was determined by measuring the PI fluorescence intensity of each cell.

\subsubsection{Cell attachment}

The cells were cultured on the surface of the samples in a 24-well plate at a density of $2 \times 10^{4}$ viable cells per sample. After $2 \mathrm{~h}$ of incubation, cells were fixed with $2.5 \%$ glutaraldehyde at $4{ }^{\circ} \mathrm{C}$ overnight and then rinsed with PBS 3 times. Afterwards, the cells were observed using confocal laser scanning microscope (CLSM; LSM700, Carl Zeiss, Oberkochen, Germany). The cells were also dehydrated in graded ethanol solutions (30\%, 50\%, 70\%, 90\%, 100\%, 100\%) and sputtered with gold for SEM analysis.

\subsubsection{Cell differentiation}

For alkaline phosphatase (ALP) activity assay, the cells were seeded on the samples $(10 \mathrm{~mm} \times 10 \mathrm{~mm} \times 1 \mathrm{~mm}, \mathrm{n}=3)$ for 1 day at a density of $2 \times 10^{4}$ cell/sample and the culture medium was changed to osteoblastinducing conditional medium, which was supplemented with $10 \mathrm{mmol} /$ L $\beta$-Glycerophosphate ( $\beta$-GP), $0.1 \mu \mathrm{mol} / \mathrm{L}$ Dexamethasone (DXMS), and $50 \mathrm{mg} / \mathrm{L}$ Vitamin C. 1 week after inducing differentiation, the cells on the sample surface were lysed and the lysis buffer was collected for determining the ALP activity and total protein using ALP test kit (Beyotime, China) and BCA protein assay kit (Beyotime, China) following the manufacturer's protocol. The ALP activity values were normalized to the total protein concentration.

For Western Blot Assay, the cells were cultured for 7 days following the method outlined above. Total proteins were collected using RIPA lysate (Saiguotech, China). After adding the loading buffer (Solarbio, China), gel electrophoresis was carried out. The protein bands were transferred to a PVDF membrane and sealed with 5\% skim milk for $1 \mathrm{~h}$. The samples were then incubated with anti-GAPDH , anti-ALP, antiRunx-2, and anti-OPN primary antibody (1:2000 dilution; Abcam, UK) overnight at $4{ }^{\circ} \mathrm{C}$ followed by secondary antibody (1:5000 dilution;
Abcam, UK) for $60 \mathrm{~min}$ at room temperature. ChemiDoc MP imaging system (Bio-Rad, USA) was used to record the protein bands.

For quantitative Real-Time PCR Analysis (qRT-PCR), the cells were cultured for 5 days following the method outlined above. Total RNA was extracted from cells using Trizol reagent (Bioteke, China) following the manufacturer's protocol. RevertAid First Strand cDNA Synthesis Kit (Thermo Fisher Scientific, USA) was used for reverse transcription. qRTPCR was completed using a SYBR premix EX TaqTM PCR kit (Takara, Japan) to evaluate the mRNA levels of ALP, Runx2, OPN. The mRNA levels were normalized to the housekeeping gene GAPDH.

\subsection{In vivo test}

12-week-old male New Zealand Rabbits $(2.5 \mathrm{Kg} \pm 0.3 \mathrm{Kg}$, Chendu Dossy Experimental Animals CO., LTD , China) were chosen to establish the mandibular bone defect model. Rabbits were randomly assigned into four groups. Animal feeding and handling were in line with the International Guidance on Animal Welfare and the Standards of the Animal Ethics Committee of the State Key Laboratory of Oral Diseases and West China School of Stomatology, Sichuan University, China (Approval number: WCHSIRB-D-2017-278). Rabbits were shaved after anesthesia (Zoletil-50, France). The composite implant (0, 0.1, 1, $5 \mathrm{wt} \%$ G-PEEK) was inserted into the defect ( $\mathrm{L}=4 \mathrm{~mm}, \mathrm{~W}=1 \mathrm{~mm}$ and $\mathrm{D}=3 \mathrm{~mm}$ ) created in the toothless area between the mandibular incisors and molars. Daily penicillin (80wU, North China Pharmaceutical Group Corporation Veterinary CO., LTD.) injection was given for 3 days after the surgery to prevent infection. The rabbits were randomly selected and sacrificed 4 and 12 weeks after the surgery. The extracted mandible bone with inserted implant was fixed in $4 \%$ paraformaldehyde for 1 week.

\subsubsection{Micro CT evaluation}

The extracted mandible bone with inserted implant of each group (n $=3$ ) were scanned with Micro-CT (Scanco Medical $\mu$-CT 50, Switzerland). The volume of interest (VOI $=100$ slices) around the implant's center point with a rectangular area of $250 \mu \mathrm{m}$ to the surface of the implant, was evaluated. The bone volume per total volume (BV/ TV), mean trabecular number (Tb.N), mean trabecular separation (Tb. $\mathrm{Sp}$ ) and mean trabecular thickness (Tb.Th) were determined after reconstruction of the VOI.

\subsubsection{Histological analysis}

The samples from each group $(\mathrm{n}=3)$ were dehydrated in graded ethanol solutions $(60 \%, 80 \%, 90 \%, 100 \%, 100 \%)$. Technovit 7200 VLC embedding solution (Heraeus Kulzer, Germany) was used for embedding the dehydrated samples. The embedding \& polymerization machine (EXAKT E520, Germany) was used to promote coagulation of the samples. The samples were sliced into $100 \mu \mathrm{m}$ slices using a slicing machine (EXAKT E300CP, Germany) followed by polishing using graded sandpapers $(320,800,1200,2500$ grit) to obtain $<50 \mu \mathrm{m}$ thick slices. The slices were cleaned by sonication for $3 \mathrm{~min}$ before staining with methylene blue and acid magenta. Image $J$ was used for the boneimplant contact ratio analysis.

\subsection{Statistical analysis}

Data were expressed as mean and standard deviation and analyzed using SPSS 16.0 software (SPSS, USA) to determine the level of significance. One-way ANOVA followed by Bonferroni's multiple comparison was applied for the statistical analysis. Values of $p<0.05$ were considered to be statistically significant; levels of significance were presented as $*(p<0.05),{ }^{* *}(p<0.01)$ and $* * *(p<0.001)$. 

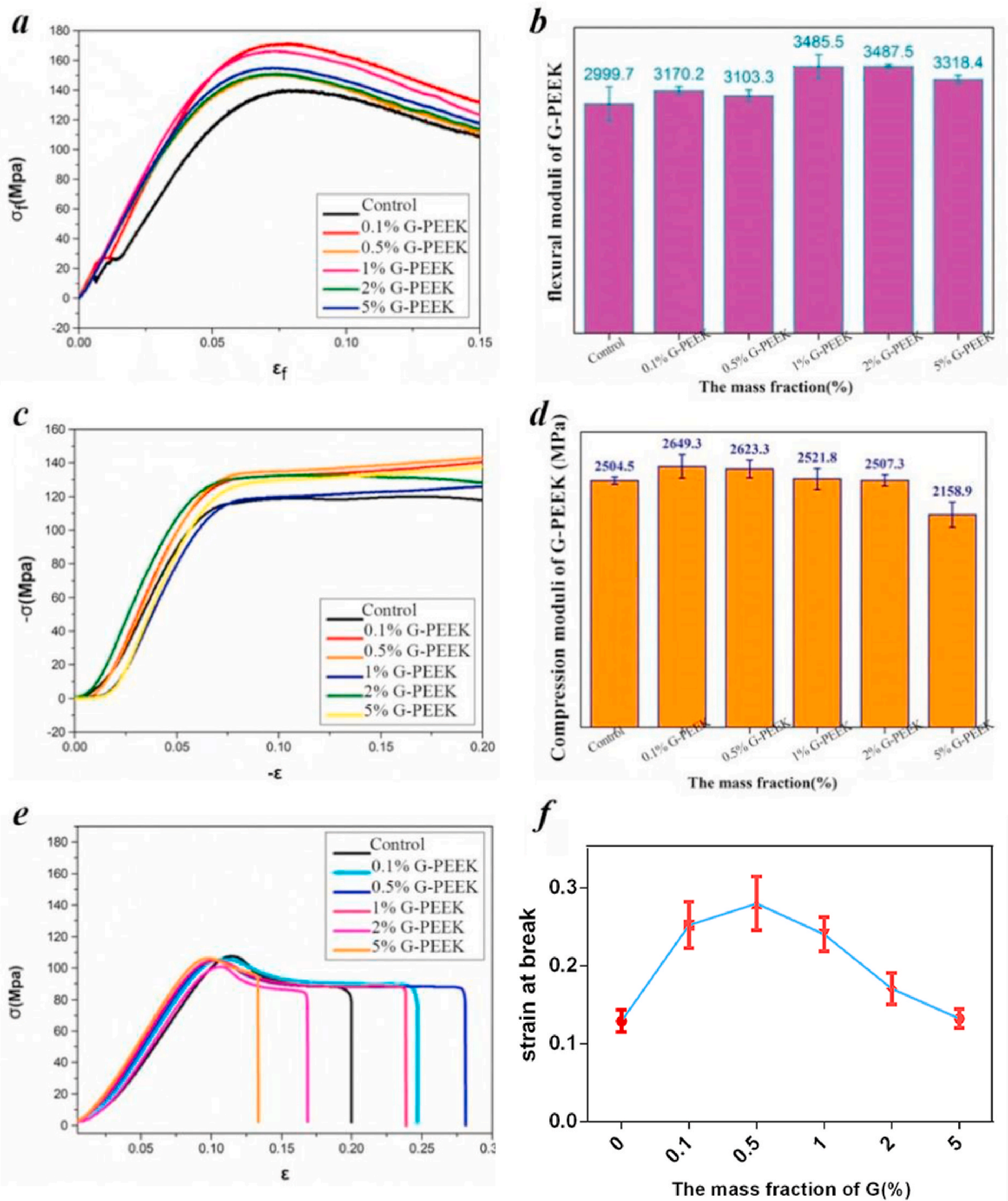

Fig. 1. The stress-strain curves (a) and moduli (b) obtained from flexural testing. The stress-strain curves (c) and moduli (d) obtained from compressive testing. The stress-strain curves (e) and (f) the stain at break for G-PEEK composites.

\section{Results and discussions}

\subsection{Materials characterization}

Fig. 1 summarized the mechanical testing results of all samples. Fig. 1a shows the typical stress-strain curves obtained from the flexural testing, where curves for all samples display similar profile. While the flexural moduli of $0.1 \%$ G-PEEK and $0.5 \%$ G-PEEK are similar to that of the pure PEEK, further addition of G (1\%) has led to approximately $10 \%$ increase in the composites flexural moduli, which gradually decrease when $\mathrm{G}$ concentration increases to $5 \%$ (see Fig. 1b). For compressive testing (Fig. 1c-d), the stress-strain curves of all samples again have similar profile. The compressive moduli of all samples are in the range of 2158-2649 MPa, similar to that of the natural cancellous bone (1, $500-2,500 \mathrm{MPa}$ ) [19]. It is also noted that 5\% G-PEEK showed $14 \%$ decrease in compressive modulus in comparison to pure PEEK. The ultimate tensile strength of all samples are in the region of 100-110 MPa (see Fig. 1e). Strain at break data in Fig. If suggests the ductility of the composites varies significantly with different $G$ concentration, with $0.5 \%$ G-PEEK showing the greatest enhancement in strain at break 
Table 2

The energy absorbed up to fracture for composites with different G concentrations.

\begin{tabular}{cllllll}
\hline $\begin{array}{l}\text { G concentration } \\
\text { (wt } \%)\end{array}$ & 0 & 0.1 & 0.5 & 1.0 & 2.0 & 5.0 \\
\hline $\begin{array}{c}\text { Energy }\left(10^{3} \mathrm{~kJ} /\right. \\
\left.\mathrm{m}^{3}\right)\end{array}$ & $\begin{array}{l}8.38 \\
\pm\end{array}$ & $\begin{array}{l}17.51 \\
\pm 0.71\end{array}$ & $\begin{array}{l}21.58 \\
\pm 0.15\end{array}$ & $\begin{array}{l}18.14 \\
\pm 1.34\end{array}$ & $\begin{array}{l}12.15 \\
\pm 2.15\end{array}$ & $\begin{array}{l}8.86 \\
\pm\end{array}$ \\
& 1.26 & & & & & 0.11 \\
\hline
\end{tabular}

( $114.33 \%$ increase) followed by $0.1 \%$ G-PEEK ( $88.29 \%$ increase) and $1 \%$ G-PEEK ( $82.04 \%$ increase). The ability of G-PEEK composite to absorb the energy up to fracture was calculated following the established procedure [36], and result has been listed in Table 2. It can be seen that at lower G concentration (e.g, $0.1 \%$ and $0.5 \%$ G-PEEK), the toughness of the composites has been enhanced more substantially, with $0.5 \%$ G-PEEK having the greatest toughness $\left(21.5810^{3} \mathrm{~kJ} / \mathrm{m}^{3}\right)$. This is $150 \%$ greater than the toughness of pure PEEK and is even greater than the toughness of the previously reported super tough graphene oxide reinforced PEEK [19]. Further increasing G concentration has led to declined toughness. This may be due to the increased $\mathrm{G}$ concentration may lead to filler agglomeration, which served as stress concentration sites and compromised the composites structural integrity [19].
The tensile fractured surface of G-PEEK samples was presented in Fig. 2a-f. The fractured surfaces of $0.5 \%$ G-PEEK and $1 \%$ G-PEEK feature ductile fracture, while the $2 \%$ G-PEEK and $5 \%$ G-PEEK fractured surfaces are typical of brittle fracture, suggesting the interaction between $G$ and the PEEK matrix is greatly influenced by the $\mathrm{G}$ concentration. The observation is also consistent with the toughness data. Fig. 3 shows the typical TEM images of G-PEEK. The contours of the embedded $G$ are clearly visible, indicating the $\mathrm{G}$ has retained its $2 \mathrm{D}$ structure. It can be observed from the images that for $\mathrm{G}$ at higher concentration (e.g. 5\%) shows sigh of agglomeration. Such agglomeration may serve as stress concentration sites and damage the he material integrity. This may partly explain the declining trend of the composite mechanical properties at higher concentration.

The crystallinity of G-PEEK composites was studied by XRD (Fig. 4a). The peaks at $18.8^{\circ}, 20.8^{\circ}, 22.8^{\circ}$, and $28.9^{\circ}$ can be attributed to the pure PEEK crystal planes (110), (111), (200), (211), respectively [37]. The XRD data shows also the graphitic peak of $\mathrm{G}$ at $26^{\circ}$; attributed to the (002) planes of GNP [38]. The slight shift of the PEEK peaks towards higher $2 \theta$ after addition of $\mathrm{G}$ signifying a change in the samples' crystallinity [39], which was later verified by the DSC analysis. It is worth noting the characteristic peak for G disappeared in all G-PEEK composites samples. The reason for this remains unclear, and it could be due
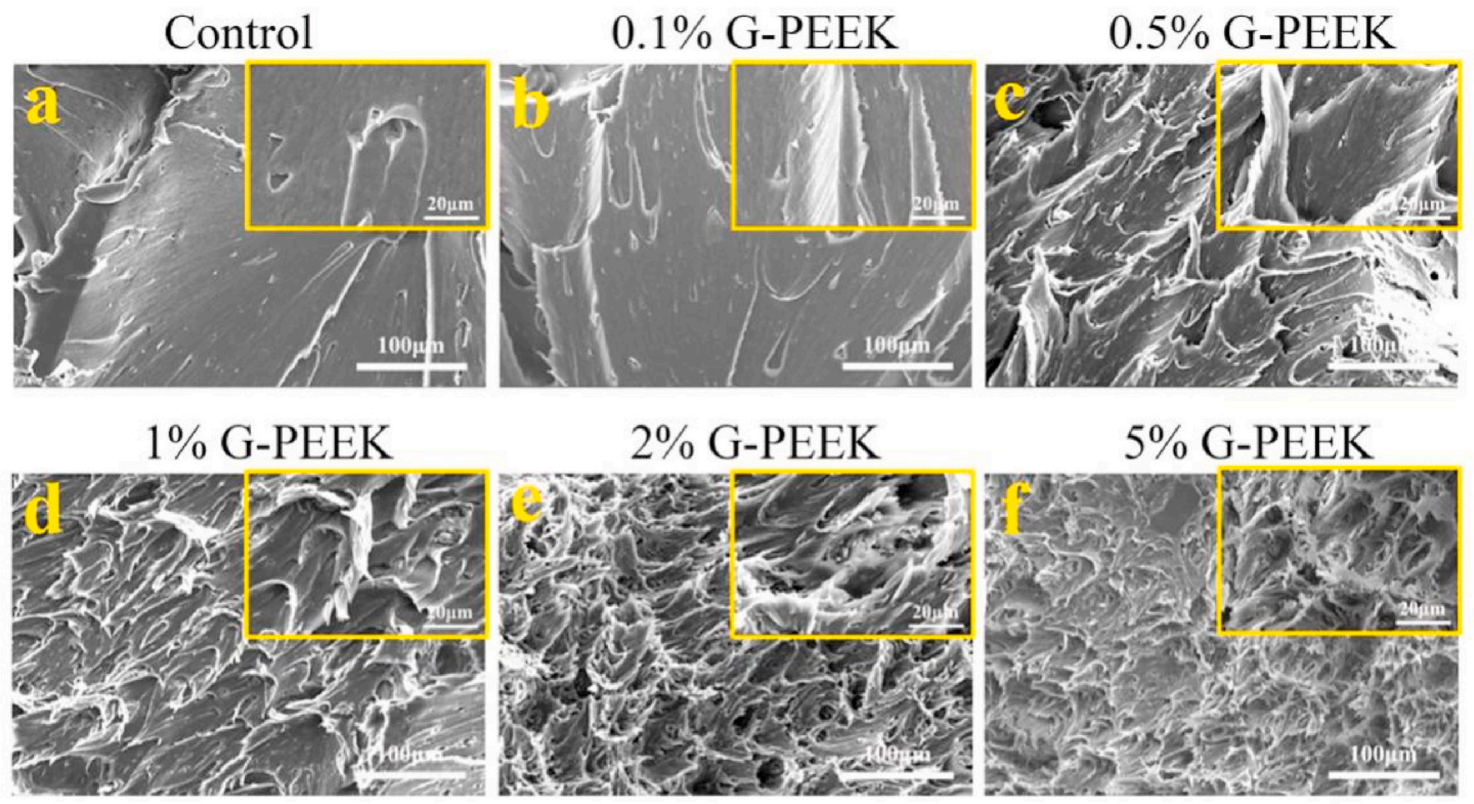

Fig. 2. Low- and high-magnification SEM images of tensile fracture surface of PEEK (a), 0.1\% G-PEEK(b), 0.5\% G-PEEK (c), 1\% G-PEEK (d), 2\% G-PEEK (e), 5\% GPEEK (f).
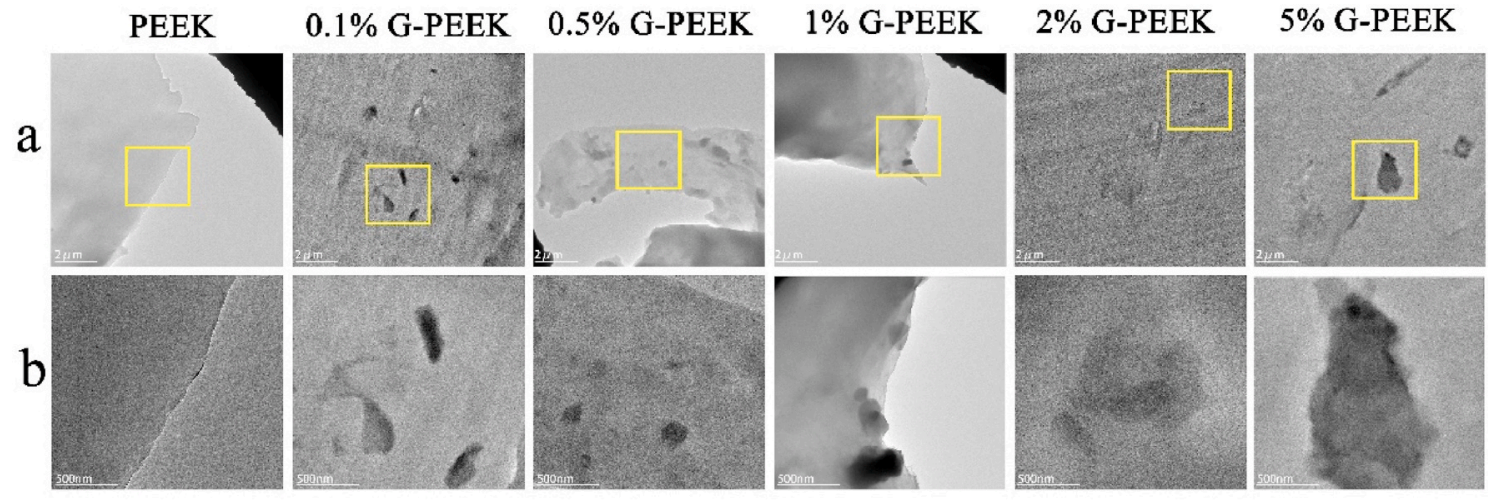

Fig. 3. TEM images of G-PEEK with low (a) and high magnifications (b). 

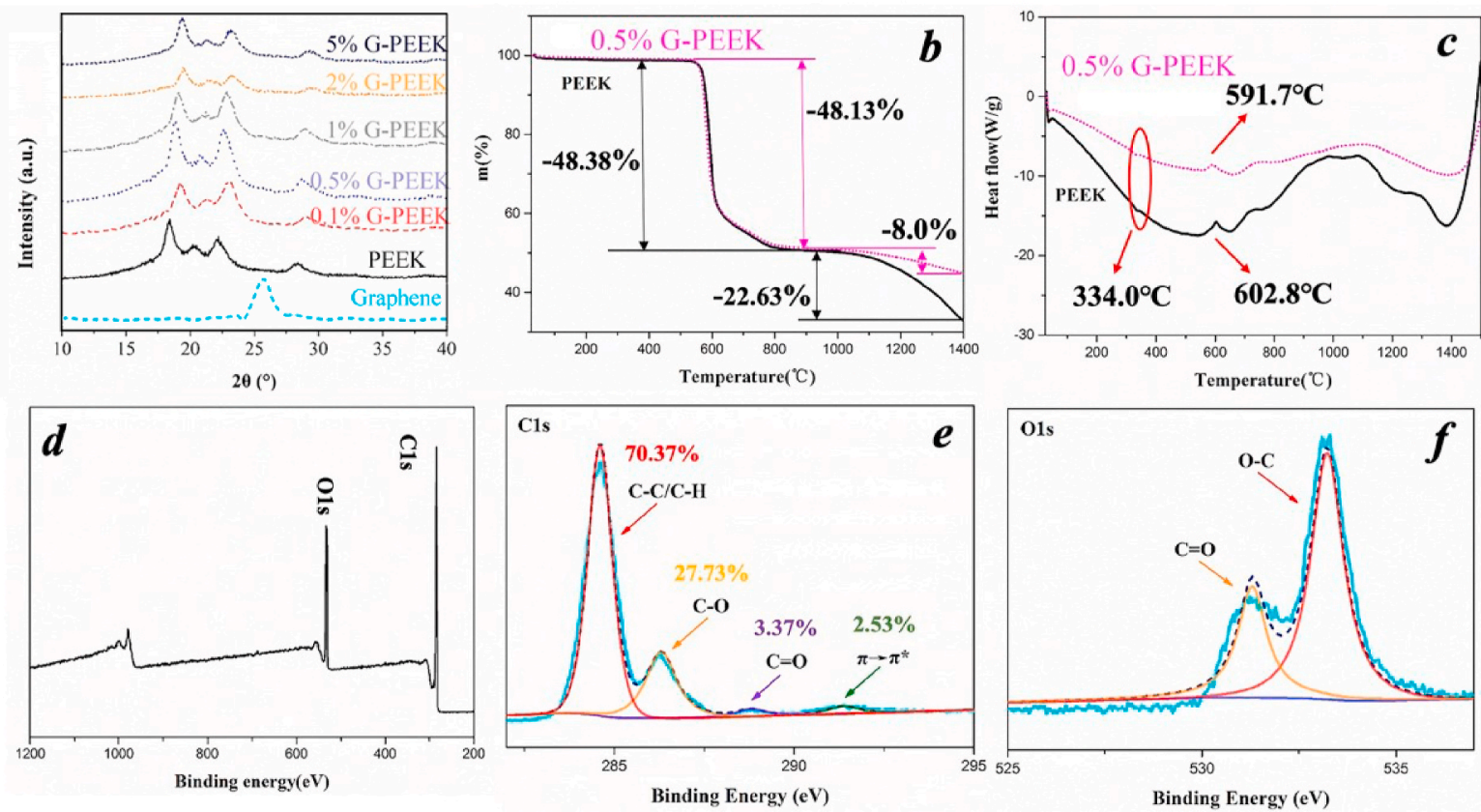

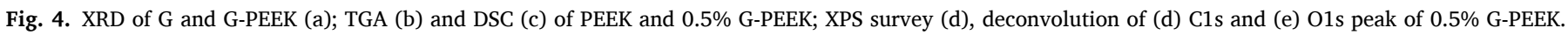
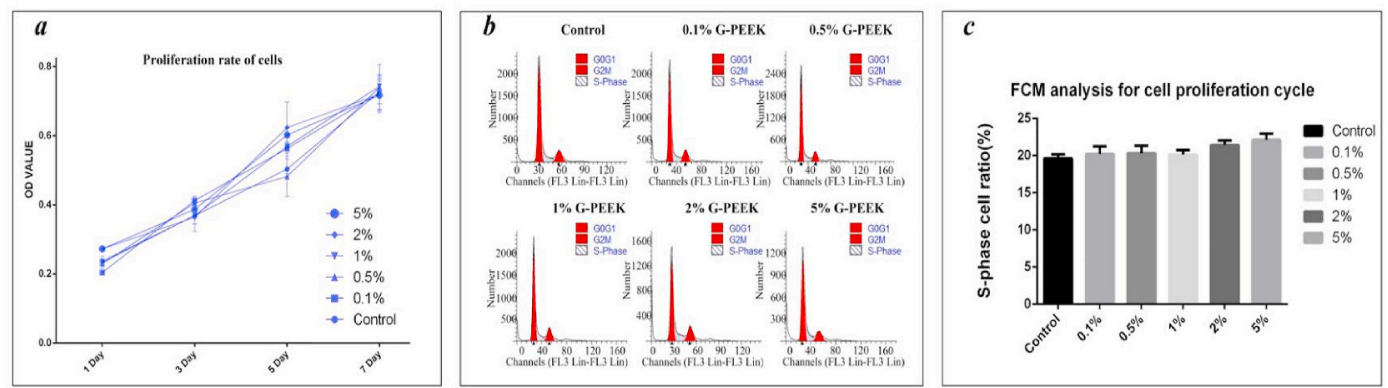

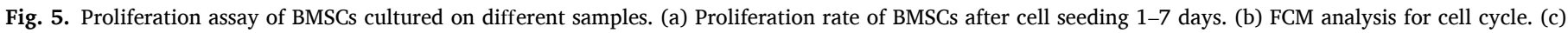
Quantitative analysis of FCM results.

to the partial overlapping of G (002) peak with the shifted PEEK (200) peaks.

Given $0.5 \%$ G-PEEK demonstrates the best toughness property amongst all samples, it was chosen for further thermal analysis and compared with pure PEEK. TGA analysis (Fig. 4b) shows that the weight loss of $0.5 \%$ G-PEEK is $48.13 \%$ up to $900{ }^{\circ} \mathrm{C}$, which is $0.20 \%$ lower than that of PEEK. Above $900{ }^{\circ} \mathrm{C}$, the weight loss of $0.5 \%$ G-PEEK is $8.0 \%$, which is $14.63 \%$ lower than that of PEEK. According to the DSC analysis (Fig. 4c), both $0.5 \%$ G-PEEK and pure PEEK have a melting point around $334{ }^{\circ} \mathrm{C}$, and the endothermic peaks around $600{ }^{\circ} \mathrm{C}$ can be attributed to the dehydrogenation and decomposition of polymer segments. The crystallinity of $0.5 \%$ G-PEEK is $31.54 \%$, much higher than that of the pure PEEK (23.16\%). This is in line with the peak shift seen in XRD analysis, and is indicative of a strong nucleation effect of the G during the melt processing [27]. The chemical information of selected $0.5 \%$ G-PEEK composite sample has been analyzed using XPS (see Fig. $4 \mathrm{~d}-\mathrm{f}$ and Figs. S1-3). The signal of C-C/C-H bond at $284.60 \mathrm{eV}, \mathrm{C}-\mathrm{O}$ bond at $286.20 \mathrm{eV}$ and $\mathrm{C}=\mathrm{O}$ bond at $289.30 \mathrm{eV}$ are evident in Fig. 4e. It is worth noting that the peak at $292.1 \mathrm{eV}$ signifies the formation of $\pi-\pi^{*}$ conjugated structure. This indicates the strong interaction between $G$ and PEEK within the G-PEEK composites. Other characteristic peaks associated with oxygen containing groups are shown in Fig. $4 \mathrm{f}$, where $531.20 \mathrm{eV}$ has been attributed to $\mathrm{O}=\mathrm{C}$ and $533.20 \mathrm{eV}$ to $\mathrm{O}-\mathrm{C}$.

\subsection{In vitro cell behavior}

Cell Proliferation. Cell proliferation is a key parameter for evaluation of biocompatibility. CCK-8 assay results (Fig. 5a) show that the cell viability of the control group (pure PEEK) and all G-reinforced PEEK implants increased on a daily basis, which indicates that all the materials under testing have good biocompatibility. There is no statistically significant difference in the cell viability among all groups $(p>0.05)$. In addition, the OD values of all G-PEEK groups do not differ significantly at any time interval, suggesting the ability of $G$ modification to accelerate cell proliferation is limited. The cell cycle progression was further examined by flow cytometry (FCM). The results (Fig. 5b-c and Fig. S4 show that despite the significant difference in $G$ concentration, the quantities of cells in the $S$ phase are similar among all G-reinforced PEEK implants $(p<0.05)$. Previous studies suggest that G-reinforcement on titanium implants could enhance pre-osteoblast cells proliferation when compared with pure titanium $[40,41]$. However, we did not observe the same impact of G on PEEK matrix even at the highest $\mathrm{G}$ concentration (5\%). It is widely accepted that the cell proliferation, particularly that of BMSCs, is sensitive to the surface topography and surface energy of the biomaterials [42]. The similar cell proliferation behavior across the implant groups under testing may be related to the similar surface topology/hydrophilicity across all samples, see Fig. S5 and Fig. S6.

Cell Adhesion. After $2 \mathrm{~h}$ of incubation of BMSCs on different implant 


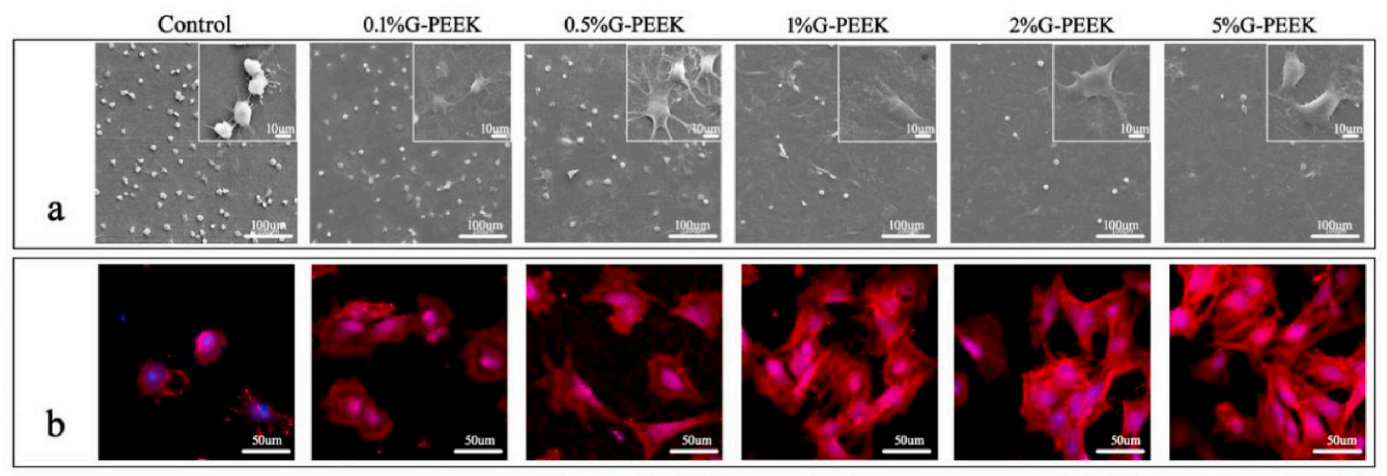

Fig. 6. BMSC morphology after 2-h incubation in each group investigated by SEM (a) and DAPI and F-actin expression (b).

$\mathbf{a}$

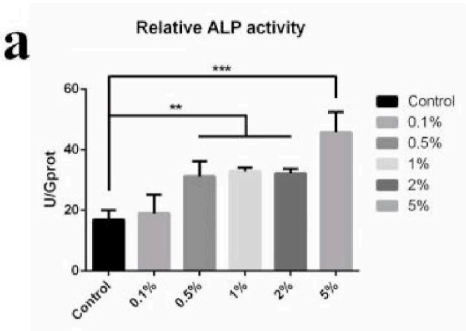

c

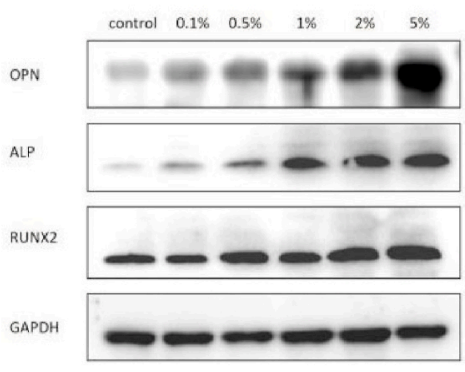

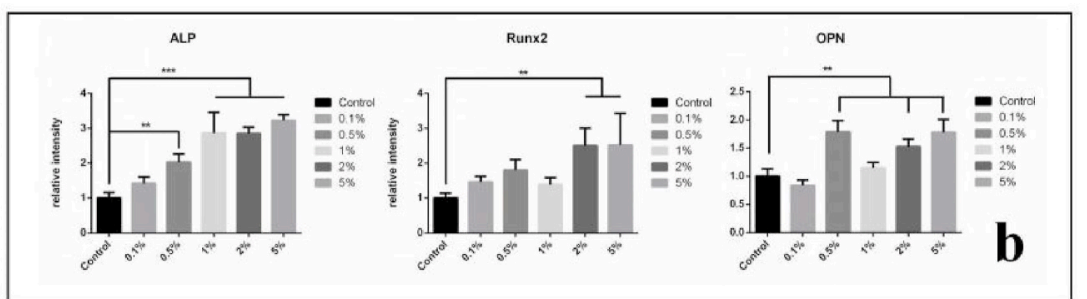

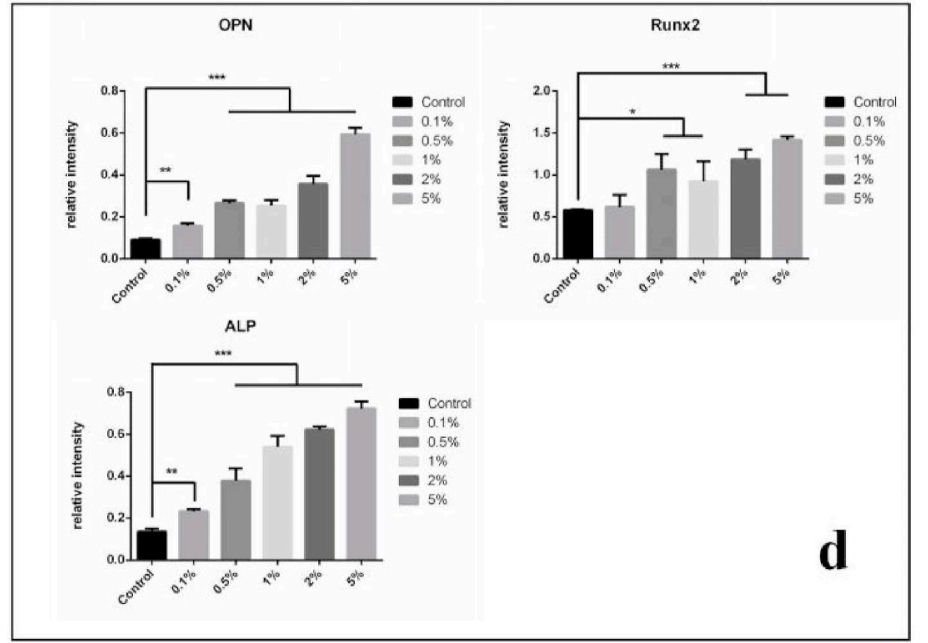

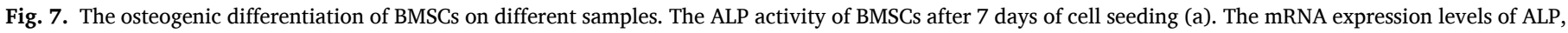
Runx-2 and OPN detected by qRT-PCR (b). Western blot assay showing expression of ALP, Runx-2 and OPN (c,d). * $p<0.05 ; * * p<0.01 ; * * * p<0.001$.

surfaces, the cell adhesion status reflected by cell morphology were illustrated in the SEM and CLSM images. On the control surface, globular cells exhibit limited spreading in spite of the abundant filopodia found on the cells' leading edge (Fig. 6a). In contrast, BMSCs on the G-reinforced samples show much better spreading, ellipsoidal with lamellipodia on $0.1 \%$ G-PEEK and $0.5 \%$ G-PEEK, or featuring polygonal morphologies on 1\% G-PEEK, $\%$ G-PEEK, and 5\% G-PEEK, respectively. This is accompanied by the increasingly organized cytoskeletons as revealed in the CLSM images in Fig. 6b. In addition, cells anchored to the G-PEEK implants displayed better interconnected lamellipodia, which is consistent with the distinctly higher F-actin expression. Since the surface morphology and wettability of the implants are similar, the results suggest that the genesis and development of cellular adherent junctions can be directly influenced by chemical composition of the material. Our data suggests that $\mathrm{G}$ modification can improve BMSC adhesion, and such effect is strengthened as $\mathrm{G}$ concentration increases.

Cell Differentiation. The ability to stimulate osteogenic differentiation of BMSCs is a crucial requirement for long-term use of bone graft materials, and it can be impacted by the material chemical composition, surface morphology, etc [43]. As shown in Fig. 7a, after 7 days of cell seeding, the relative ALP activity of BMSCs cultured on the G- PEEK samples are significantly greater than that of the control sample $(p<$ 0.01 ), and the BMSCs on 5\% G-PEEK show the highest value $(p<0.001)$. The mRNA expression of ALP, unt-related transcription factor 2 (Runx-2) and osteopontin (OPN) of BMSCs cultured on the different samples were also assessed (Fig. 7b). Compared to the control sample, ALP, Runx-2 and OPN expression levels are prominently upregulated in the G-PEEK samples (except 0.1\% G-PEEK). Similar to results of the ALP activity assay, the strongest osteogenesis enhancement reflected by Runx-2 (the early marker in osteoblastic differentiation), and OPN (a late-stage marker), is found on 5\% G-PEEK samples. Subsequently, the protein expression level of osteogenic factors of BMSCs on different samples has been determined. As shown in Fig. 7c, protein expression of ALP, Runx-2 and OPN are upregulated as G concentration increases, and the result was further quantified in Fig. $7 \mathrm{~d}$. 

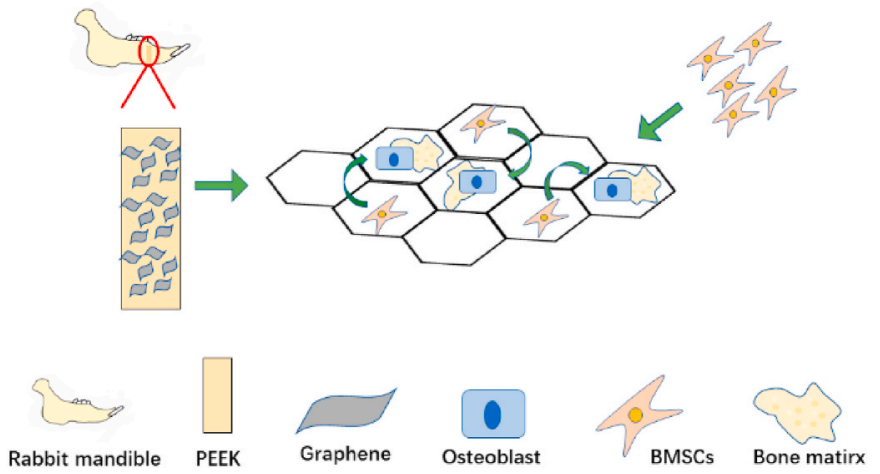

Fig. 8. Schematic diagram showing how G-PEEK promotes bone repair.

\subsection{In vivo study}

Since $0.5 \%, 1 \%$ and $2 \%$ G-PEEK had similar in vitro performance, only the control, $0.1 \%$ G-PEEK, 1\% G-PEEK and 5\% G-PEEK were selected for the in vivo study. Weeks 4 and 12 post-surgery were chosen to represent the early stage osseointegration and the late stage of bone growth, respectively. Successful healing has been achieved in all four groups and all the endosseous implants remained well-positioned inside the mandible. Schematic in Fig. 8 illustrates the mechanism involved in the bone repair process.

Micro-CT images in Fig. 9 shows the effects of G-reinforced PEEK on osseointegration and effects of different $\mathrm{G}$ concentrations. Compared with the control and 0.1\% G-PEEK, 1\% G-PEEK and 5\% G-PEEK are surrounded with greater amount of bone. Based on quantitative analysis, BV/TV, Tb.Th and Tb.N increase and Tb. sp decreases with increasing G concentration. The results of week 4 and 12 are consistent. Although there is no statistic difference in Tb.Th, Tb.N and Tb. sp amongst all groups, 1\% G-PEEK and 5\% G-PEEK have remarkably boosted BV/TV ( $p$ $<0.01)$ compared with the control. In addition, the images of undecalcified sections with PEEK materials and the corresponding histomorphometry corroborate the Micro-CT results. As shown in Fig. 10, G-PEEK samples are covered with a greater amount of bone tissue in contrast to the control PEEK, especially for week 12 after surgery. The greatest amount of dense and thick bone can be found on the 5\% G-PEEK implant surface, suggesting the best interfacial bonding with the surrounding trabeculae and the best bone reformation performance.
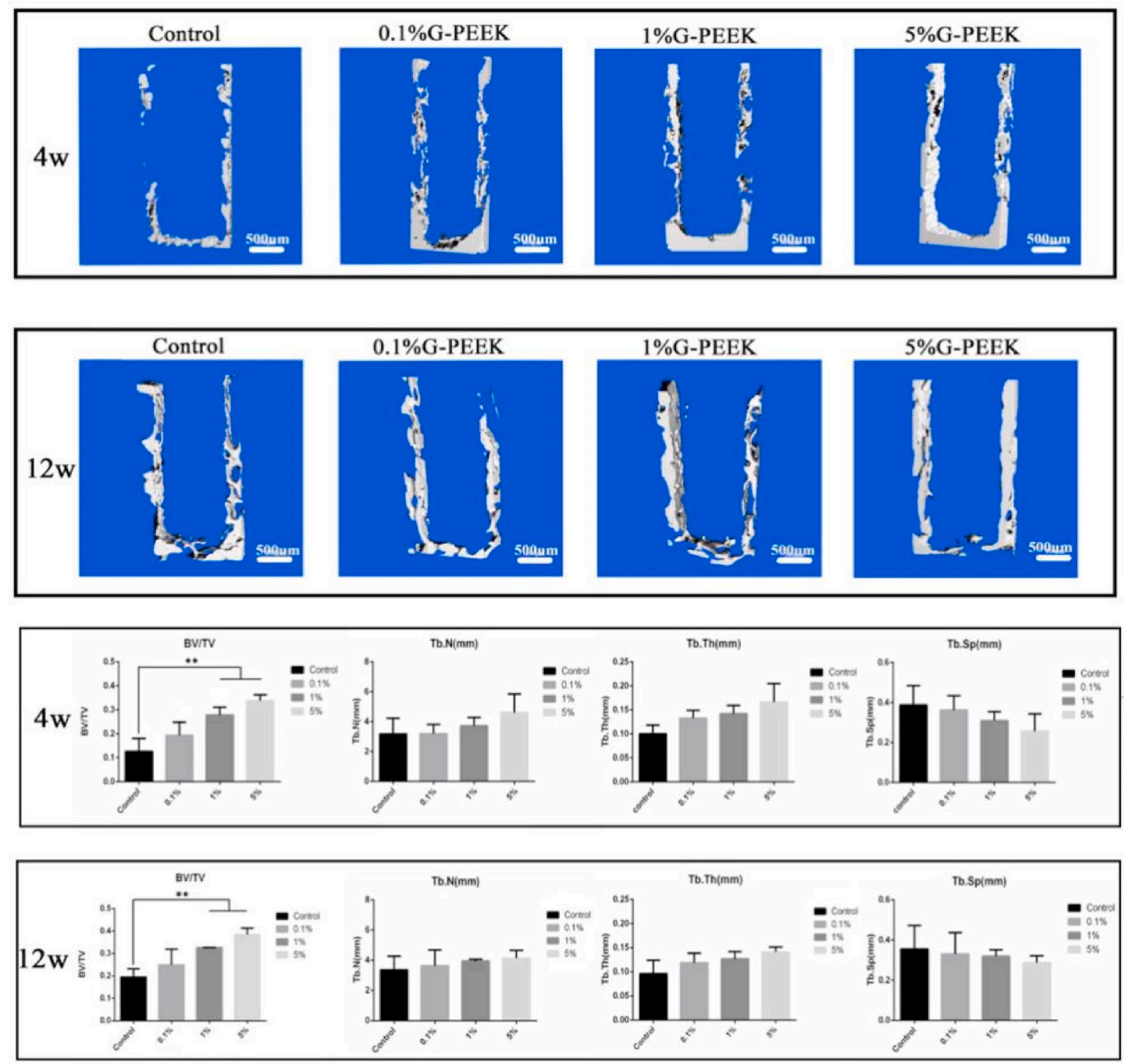

Fig. 9. Micro-CT images showing the VOI in transverse planes and qualitative analysis of osseointegration 4 and 12 weeks after surgery. $* * p<0.01$. 

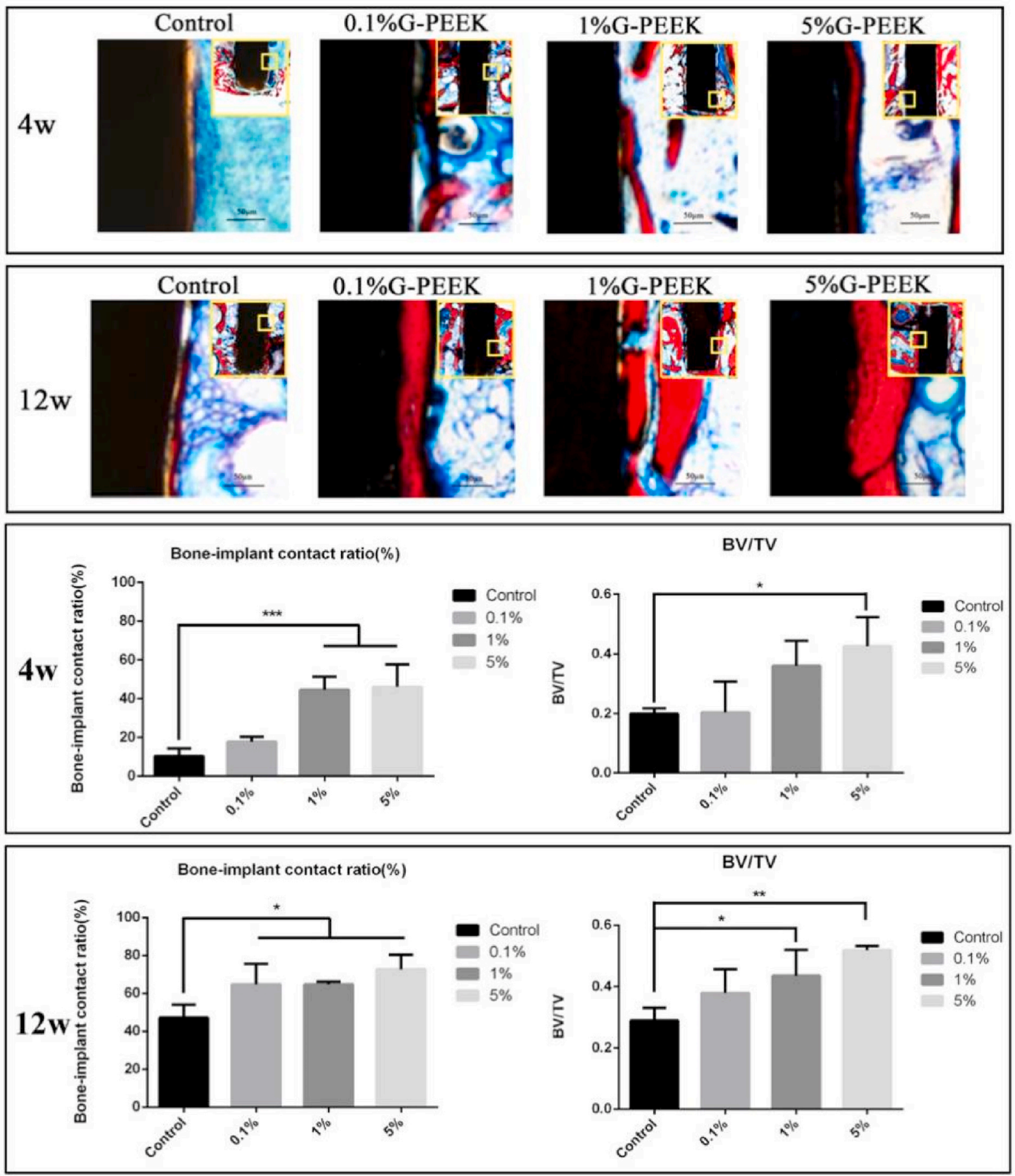

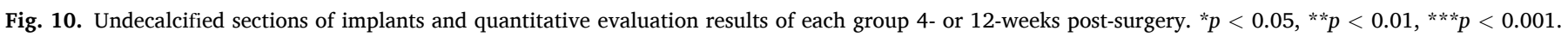

Quantitatively, 5\% G-PEEK group shows the greatest BV/TV among all groups $(p<0.01)$ at any point of time, and 1\% G-PEEK $(p<0.05)$ showed higher BV/TV value than the control at week 12 . Both $1 \%$ GPEEK and 5\% G-PEEK demonstrated superior BIC when compared with the control $(p<0.001)$ in week 4 while all G-PEEK groups showed greater BIC value than the control $(p<0.05)$ after a 12 -week period of peri-implant new bone accumulation. The experimental results suggest that all G-PEEK samples possess excellent bioactivity and the capability to integrate with the new bone with 5\% G-PEEK showing the best performance in general.

Various studies have confirmed the osteogenic effect of $\mathrm{G}$ in implant materials [44], However, the use of G in PEEK based implant is still in its infancy. In the current study, both in vitro and in vivo results demonstrate that $5 \%$ G-PEEK has the best performance in promoting cell adhesion, osteogenic differentiation and osseointegration - the three key factors for assessing materials' biological properties in vitro. In consideration of the undifferentiated cell proliferation on all groups, the promoted osseointegration and bone regeneration in vivo should originate from other cell-material interactions besides cell proliferation. It has been accepted that the cell spreading and cell-cell, cell-substrate interactions are crucial for regulation of bone regeneration [45]. Kim et al. reported that the G-based substrate could influence cell morphology and interaction, which might be a possible explanation for the enhanced bone regeneration [46]. Our results further support this claim. Moreover, the 
in vivo osteogenic enhancement may also be due to that BMSC differentiation towards adipocytes has been greatly suppressed by G, as insulin, a key regulator for the synthesis of fatty acids, can be denatured due to $\pi-\pi^{*}$ formation on $\mathrm{G}$ [47].

It is noteworthy that the in vivo performance of G-reinforced PEEK is improved as $\mathrm{G}$ concentration increases, and the beneficial bone regeneration effect peaks at $5 \% \mathrm{G}$ in our study. Nonetheless, high G concentration (greater than $1 \mathrm{wt} \%$ ) can lead to declined composite toughness. Therefore, in practical use of G-PEEK, consideration should be given to balancing the demand for the biological performance and mechanical properties when selecting the suitable implant composition.

\section{Conclusion}

In the present study, $\mathrm{G}$ was introduced into PEEK to produce bone implant material via injection moulding. Results show that addition of 0.1 and $0.5 \mathrm{wt} \% \mathrm{G}$ can lead to significantly enhanced composite toughness. The bioactivity of PEEK has been significantly improved after $\mathrm{G}$ modification. Increased osteogenesis and osseointegration were observed on the G-PEEK implants with increasing G concentration, with 5\% G-PEEK demonstrating the best tissue regeneration performance both in vitro and in vivo. The promising results show the strong potential of our G-reinforced nanocomposites in future bone implants (such orthopedic and dental devices) applications. However, high G concentration would lead to compromised mechanical properties (e.g. toughness). Therefore, in practical use of G-PEEK implants, one would need to balance the demand for the biological performance and mechanical properties when selecting the suitable $\mathrm{G}$ concentration for the composite implants.

\section{Author statement}

Nan Jiang : Writing- Original draft preparation, Methodology, Visualization.

Peijie Tan : Writing- Original draft preparation, Formal analysis , Visualization.

Miaomiao He : Validation.

Jie Zhang : Investigation.

Dan Sun : Writing - Review \& Editing.

Songsong Zhu : Conceptualization, Funding acquisition , Writing Review \& Editing, Supervision.

\section{Declaration of competing interest}

The authors declare that they have no known competing financial interests or personal relationships that could have appeared to influence the work reported in this paper.

\section{Acknowledgements}

This study was supported by grants from the National Natural Science Foundation of China (No. $81771097 \&$ No.81901026) and the Department of Science and Technology of Sichuan Province (No. 2019YJ0103\& No.2021YFH0139).

\section{Appendix A. Supplementary data}

Supplementary data to this article can be found online at https://doi. org/10.1016/j.polymertesting.2021.107276.

\section{References}

[1] A.A. Moussa, J. Fischer, R. Yadav, M. Khandaker, Minimizing stress shielding and cement damage in cemented femoral component of a hip prosthesis through computational design optimization, Adv Orthop (2017) (2017) 8437956.
[2] H. Wang, K. Su, L. Su, P. Liang, P. Ji, C. Wang, Comparison of 3D-printed porous tantalum and titanium scaffolds on osteointegration and osteogenesis, Mater Sci Eng C Mater Biol Appl 104 (2019) 109908.

[3] N. Jiang, Z. Guo, D. Sun, Y. Li, Y. Yang, C. Chen, L. Zhang, S. Zhu, Promoting osseointegration of $\mathrm{Ti}$ implants through micro/nanoscaled hierarchical Ti phosphate/Ti oxide hybrid coating, ACS Nano 12 (2018) 7883-7891.

[4] M. Ranjani, A. G. Al Sehemi, M. Pannipara, M.A. Aziz, S.M. Phang, F.L. Ng, G. G. kumar, SnO2 nanocubes/bentonite modified SPEEK nanocomposite composite membrane for high performance and durable direct methanol fuel cells, Solid State Ionics 353 (2020) 115318.

[5] G. Gnana kumar, A. Manthiram, Sulfonated polyether ether ketone/strontium zirconite@TiO2 nanocomposite membranes for direct methanol fuel cells, J. Mater. Chem. 5 (2017) 20497-20504.

[6] M. He, Y. Huang, H. Xu, G. Feng, L. Liu, Y. Li, D. Sun, L. Zhang, Modification of polyetheretherketone implants: from enhancing bone integration to enabling multi-modal therapeutics, Acta Biomater. (2021 May 18), https://doi.org/ 10.1016/j.actbio.2021.05.009.

[7] J.H. Yan, C.H. Wang, K.W. Li, Q. Zhang, M. Yang, W.L. Di Wu, M. Yan, Y. Song, J. J. Ba, L. Bi, Y.S. Han, Enhancement of surface bioactivity on carbon fiberreinforced polyether ether ketone via graphene modification, Int. J. Nanomed. 13 (2018) 3425-3440.

[8] M.S. Abu Bakar, P. Cheang, K.A. Khor, Mechanical properties of injection molded hydroxyapatite-polyetheretherketone biocomposites, Compos. Sci. Technol. 63 (2003) 421-425.

[9] D. Almasi, W.J. Lau, S. Rasaee, R. Sharifi, H.R. Mozaffari, Fabrication of a novel hydroxyapatite/polyether ether ketone surface nanocomposite via friction stir processing for orthopedic and dental applications, Prog Biomater 9 (2020) 35-44.

[10] L. Bathala, V. Majeti, N. Rachuri, N. Singh, S. Gedela, The role of polyether ether ketone (peek) in dentistry - a Review, J Med Life 12 (2019) 5-9.

[11] B. Yuan, Q. Cheng, R. Zhao, X. Zhu, X. Yang, X. Yang, K. Zhang, Y. Song, X. Zhang, Comparison of osteointegration property between PEKK and PEEK: effects of surface structure and chemistry, Biomaterials 170 (2018) 116-126.

[12] M.S. Abu Bakar, M.H.W. Cheng, S.M. Tang, S.C. Yu, K. Liao, C.T. Tan, K.A. Khor, P. Cheang, Tensile properties, tension-tension fatigue and biological response of polyetheretherketone-hydroxyapatite composites for load-bearing orthopedic implants, Biomaterials 24 (2003) 2245-2250.

[13] M. He, C. Zhu, H. Xu, D. Sun, C. Chen, G. Feng, L. Liu, Y. Li, L. Zhang, Conducting polyetheretherketone nanocomposites with an electrophoretically deposited bioactive coating for bone tissue regeneration and multimodal therapeutic applications, Acs Appl Mater Inter 12 (2020) 56924-56934.

[14] A.M. Díez-Pascual, A. L. Díez Vicente, Nano-TiO2 reinforced PEEK/PEI blends as biomaterials for load-bearing implant applications, Acs Appl Mater Inter 7 (2015) $5561-5573$.

[15] S. Najeeb, Z.K. Bds, S.Z. Bds, M.S. Bds, Bioactivity and osseointegration of PEEK are inferior to those of titanium: a systematic Review, J. Oral Implantol. 42 (2016) 512-516.

[16] J. Salamon, Y. Sathishkumar, K. Ramachandran, Y.S. Lee, D.J. Yoo, A.R. Kim, G. Gnana kumar, One-pot synthesis of magnetite nanorods/graphene composites and its catalytic activity toward electrochemical detection of dopamine, Biosens. Bioelectron. 64 (2015) 269-276.

[17] G. Gnana kumar, C. Joseph Kirubaharan, D.J. Yoo, A.R. Kim, Graphene/poly(3,4ethylenedioxythiophene)/Fe3O4 nanocomposite - an efficient oxygen reduction catalyst for the continuous electricity production from wastewater treatment microbial fuel cells, Int. J. Hydrogen Energy 41 (2016) 13208-13219.

[18] D. Sun, M. Tang, L. Zhang, B.G. Falzon, D.B. Padmanaban, D. Mariotti, P. Maguire, H. Xu, M. Chen, D. Sun, Microplasma assisted synthesis of gold nanoparticle/ graphene oxide nanocomposites and their potential application in SERS sensing, Nanotechnology 30 (2019) 455603.

[19] Z. Guo, N. Jiang, J. Moore, C.P. McCoy, M. Ziminska, C. Rafferty, G. Sarri, A. R. Hamilton, Y. Li, L. Zhang, S. Zhu, D. Sun, Nanoscale hybrid coating enables multifunctional tissue scaffold for potential multimodal therapeutic applications, Acs Appl Mater Inter 11 (2019) 27269-27278.

[20] Z. Su, D. Sun, L. Zhang, M. He, Y. Jiang, B. Millar, P. Douglas, D. Mariotti, P. Maguire, D. Sun, Chitosan/silver nanoparticle/graphene oxide nanocomposites with multi-drug release, antimicrobial, and photothermal conversion functions, Materials 14 (2021).

[21] M. He, X. Chen, Z. Guo, X. Qiu, Y. Yang, C. Su, N. Jiang, Y. Li, D. Sun, L. Zhang, Super tough graphene oxide reinforced polyetheretherketone for potential hard tissue repair applications, Compos. Sci. Technol. 174 (2019) 194-201.

[22] Y. Liu, T. Chen, F. Du, M. Gu, P. Zhang, X. Zhang, J. Liu, L. Lv, C. Xiong, Y. Zhou, Single-layer graphene enhances the osteogenic differentiation of human mesenchymal stem cells in vitro and in vivo, J. Biomed. Nanotechnol. 12 (2016) 1270-1284.

[23] S.D. Newby, T. Masi, C.D. Griffin, W.J. King, A. Chipman, S. Stephenson, D. E. Anderson, A.S. Biris, S.E. Bourdo, M. Dhar, Functionalized graphene nanoparticles induce human mesenchymal stem cells to express distinct extracellular matrix proteins mediating osteogenesis, Int. J. Nanomed. 15 (2020) 2501-2513.

[24] P. Noorunnisa Khanam, M.A. AlMaadeed, M. Ouederni, B. Mayoral, A. Hamilton, D. Sun, Effect of two types of graphene nanoplatelets on the physico-mechanical properties of linear low-density polyethylene composites, Adv. Manuf. Polym. Compos. Sci. 2 (2016) 67-73.

[25] P. Noorunnisa Khanam, M.A. AlMaadeed, M. Ouederni, E. Harkin-Jones, B. Mayoral, A. Hamilton, D. Sun, Melt processing and properties of linear low density polyethylene-graphene nanoplatelet composites, Vacuum 130 (2016) 63-71. 
[26] P.N. Khanam, M.A. AlMaadeed, S. AlMaadeed, S. Kunhoth, M. Ouederni, D. Sun, A. Hamilton, E.H. Jones, B. Mayoral, Optimization and prediction of mechanical and thermal properties of graphene/LLDPE nanocomposites by using artificial neural networks, Int J Polym Sci 2016 (2016) 5340252.

[27] B. Mayoral, E. Harkin-Jones, P.N. Khanam, M.A. AlMaadeed, M. Ouederni, A. R. Hamilton, D. Sun, Melt processing and characterisation of polyamide 6/ graphene nanoplatelet composites, RSC Adv. 5 (2015) 52395-52409.

[28] Y. Jiang, Y. Yang, X. Zheng, Y. Yi, X. Chen, Y. Li, D. Sun, L. Zhang, Multifunctional load-bearing hybrid hydrogel with combined drug release and photothermal conversion functions, NPG Asia Mater. 12 (2020) 18.

[29] X.Y. Li, Y.H. Xiao, A. Bergeret, M. Longerey, J.F. Che, Preparation of polylactide/ graphene composites from liquid-phase exfoliated graphite sheets, Polym. Compos. 35 (2014) 396-403.

[30] H.N. Lim, N.M. Huang, S.S. Lim, I. Harrison, C.H. Chia, Fabrication and characterization of graphene hydrogel via hydrothermal approach as a scaffold for preliminary study of cell growth, Int. J. Nanomed. 6 (2011) 1817-1823.

[31] M.F. Arif, H. Alhashmi, K.M. Varadarajan, J.H. Koo, A.J. Hart, S. Kumar, Multifunctional performance of carbon nanotubes and graphene nanoplatelets reinforced PEEK composites enabled via FFF additive manufacturing, Compos. B Eng. 184 (2020) 10.

[32] A.G. Littlefield, J.A. Maurer, S.F. Bartolucci, A Study on the Use of Graphene-PEEK Composites as High Temperature Adhesives: Mechanical Properties and Microwave Activation, ASME 2017 International Mechanical Engineering Congress and Exposition, UNSP V014T11A041, 2017, p. 14.

[33] L. Liu, F. Yan, F. Gai, L. Xiao, L. Shang, M. Li, Y. Ao, Enhanced tribological performance of PEEK/SCF/PTFE hybrid composites by graphene, RSC Adv. 7 (2017) 33450-33458.

[34] A. Alvaredo, M.I. Martin, P. Castell, R. Guzman de Villoria, J.P. FernandezBlazquez, Non-isothermal crystallization behavior of PEEK/graphene nanoplatelets composites from melt and glass states, Polymers 11 (2019) 124.

[35] A. Alvaredo-Atienza, J.P. Fernandez-Blazquez, P. Castell, R. Guzman de Villoria, Production of graphene nanoplate/polyetheretherketone composites by semiindustrial melt-compounding, Heliyon 6 (2020), e03740.

[36] R. Zhu, E. Pan, A.K. Roy, Molecular dynamics study of the stress-strain behavior of carbon-nanotube reinforced Epon 862 composites, Mater. Sci. Eng. 447 (2007) $51-57$.
[37] P.C. Dawson, D.J. Blundell, X-ray data for poly(aryl ether ketones), Polymer 21 (1980) 577-578.

[38] R. Siburian, H. Sihotang, S.L. Raja, M. Supeno, C. Simanjuntak, New route to synthesize of graphene nano sheets, Orient. J. Chem. 34 (2018) 182-187.

[39] M.I. Fareed, Effect of operating conditions on the tribological performance of polyether ether ketone (PEEK), Adv. Polym. Technol. 37 (2018) 1537-1543.

[40] Y.Y. Shi, M. Li, Q. Liu, Z.J. Jia, X.C. Xu, Y. Cheng, Y.F. Zheng, Electrophoretic deposition of graphene oxide reinforced chitosan-hydroxyapatite nanocomposite coatings on Ti substrate, J. Mater. Sci. Mater. Med. 27 (2016) 48.

[41] N. Karimi, M. Kharaziha, K. Raeissi, Electrophoretic deposition of chitosan reinforced graphene oxide-hydroxyapatite on the anodized titanium to improve biological and electrochemical characteristics, Mater Sci Eng C Mater Biol Appl 98 (2019) 140-152.

[42] N. Jiang, Z. Guo, D. Sun, B. Ay, Y. Li, Y. Yang, P. Tan, L. Zhang, S. Zhu, Exploring the mechanism behind improved osteointegration of phosphorylated titanium implants with hierarchically structured topography, Colloids Surf., B 184 (2019) 110520.

[43] A.S.G. Curtis, B. Casey, J.O. Gallagher, D. Pasqui, M.A. Wood, C.D.W. Wilkinson, Substratum nanotopography and the adhesion of biological cells. Are symmetry or regularity of nanotopography important? Biophys. Chem. 94 (2001) 275-283.

[44] S. Asim, Y. Zhu, M. Rana, J. Yin, M.W. Shah, Y. Li, C. Wang, Nanostructured 3Dporous graphene hydrogel based $\mathrm{Ti} / \mathrm{Sb}-\mathrm{SnO} 2-\mathrm{Gr}$ electrode with enhanced electrocatalytic activity, Chemosphere 169 (2017) 651-659.

[45] J. Kim, W.G. Bae, S. Park, Y.J. Kim, I. Jo, S. Park, N.L. Jeon, W. Kwak, S. Cho, J. Park, Engineering structures and functions of mesenchymal stem cells by suspended large-area graphene nanopatterns, 2D Mater. 3 (2016), 035013.

[46] J. Kim, Y.R. Kim, Y. Kim, K.T. Lim, H. Seonwoo, S. Park, S.P. Cho, B.H. Hong, P. H. Choung, T.D. Chung, Y.H. Choung, J.H. Chung, Graphene-incorporated chitosan substrata for adhesion and differentiation of human mesenchymal stem cells, J. Mater. Chem. B 1 (2013) 933-938.

[47] W.C. Lee, C.H. Lim, H. Shi, L.A. Tang, Y. Wang, C.T. Lim, K.P. Loh, Origin of enhanced stem cell growth and differentiation on graphene and graphene oxide, ACS Nano 5 (2011) 7334-7341. 